\title{
ANALYSIS OF POVERTY IN FOREST SURROUNDING COMMUNITIES BY SUSTAINABLE LIVELIHOOD APPROACH
}

\author{
Rita Parmawati ${ }^{1}{ }^{5}$, Soemarno $^{2}$, Maryunani ${ }^{3}$, Agung Sih Kurnianto ${ }^{4}$

\begin{abstract}
Poverty in forests surrounding communities shows a contrast between wealth of forest resources and poverty. The Poverty of forests surrounding communities is seen as inefficient development to rural needs in general and forest management in particular. This study aims to analyze the factors affecting poverty, the relevance and sustainable livelihood approach in poverty. This research was conducted in the Village of Argosari, J abung Sub-district and the Village of Mentaraman, Donomulyo District, Malang Regency. Sustainable livelihood approach is applied which adapted on five elements: human, natural, physical, social and financial asset. The sample was determined by proportional random sampling method. Participatory Rapid Appraisal (PRA) were used in this study. The quantitative approach in this study using descriptive analysis and Structural Equation Modeling (SEM). Poverty Gap 2 indicator (the number of family member) has the greatest contribution to Argosari poverty. The High Consumption 3 indicator (the number of new clothing in a year that can be bought) has the smallest contribution. Significantly, eight indicators have established in the Mentaraman, which is indicated by a p-value less than $5 \%(0.05)$. Based on the size of the standardize coefficient, it is found that the Poverty Gap 2 indicator (the number of family member) has the greatest contribution to the Mentaraman poverty.
\end{abstract}

Keywords : Argosari, Forest, Mentaraman, Poverty, SLA

\section{A. INTRODUCTION}

$D$ overty in forests surrounding commu nities shows a contrast between the poverty conditions of households that have a wealth of surrounding forest resources. Some authors argue that poverty around the forest is not a single-dimensional problem (Fisher, 2004; Plumptre et al., 2004).

\footnotetext{
${ }^{1}$ Postgraduate, Brawijaya University, Malang

${ }^{2}$ Agriculture Faculty, Brawijaya University, Malang

${ }^{3}$ Economy Faculty, Brawijaya University, Malang

${ }^{4}$ Ecology and Animal Diversity Laboratory, Biology Departement, Brawijaya University, Malang

${ }^{5}$ Corresponding Author:

Email: ritaparmawati1990@gmail.com

DOI: 10.25077/jantro.v20.n1.p1-15.2018

JANTRO ISSN: 2355-5963 (Online)
}

under Lisensi Creative Commons Atribusi-BerbagiSerupa 4.0 Internasional
Poverty around forests is seen as a multidimensional problem that is closely linked to inefficient development and is not speci fically applied to rural needs in general and forest management in particular $\mathrm{Li}, 2002$; Angelsen and Wunder, 2003; Dewi et al., 2005; Sunderlin et al., 2005; Yoserizal., and Yesi (2018), rural development (Husken, 1998), and various social exclusion pro cesses occurring as a result of forestry laws and government policies in the forestry sector (Kartodi hardjo, 2006; Mamo et al., 2007; Vedeld et al., 2012) are the dimen sions of poverty in forest area.

Modernization and regional deve lopment continues, but the role of forests has not been replaced. Most of the forest edge community's income sources come from forests, whether for consumption, culture or 
cash money (Lyman et al., 2014; Fikir et al., 2016). The number of poverty around the forest is poorly recorded. Based on the analysis, it is estimated that $50 \%$ of the poor are from forest edge communities (Ananta et al., 2013). This illustrates the number of poor people in the edge of forests in Indonesia is greater than other areas outside of forest and urban areas (BPS, 1999). However, these facts are under-paid by governments that are required to make poverty reduction policies. Poverty alleviation policies are more likely to be biased toward the poor in urban areas or villages outside the forest area (Hamzah, 2012).

Poverty reduction policies need to be specific to reveal the problems. The edge forest poverty characterized by process of marginalization in the hinterland, the im balance of village development, the unopti mization of natural resources, and the culture of the community.

In other side, Sustainable Livelihood Approach (SLA) is a system that aims to build a degree of socio-economic welfare that is not only oriented to the accumulation of instantaneous asset, but is more concerned to fulfill the needs of future generations with the same quantity and quality (Krantz, 2001; Morse and McNamara, 2013; Munanura et al., 2014). Village development guided by the idea of sustainability has a clear platform on strengthening the structure of community organizations to fully manage the natural resources based on local wisdom in accordance with ethosocentric ethics. The SLA approach refers to local contextual facts in community. A model of job strategy that interacts directly with environmental sus tainability is established by 5 main assets: social, natural, human, financial, and phy sical (Krantz, 2001).

Argosari and Mentaraman are a figure of poor villages, but surrounded by abundant natural resources. Both village are the red areas (poor areas) according to East Java Community Empowerment Institution (BPM Jawa Timur). The 1997 economic crisis caused enormous defo restation. Com munities are pressed to meet their daily needs, thus using the forest area as agricultural land. In addition, there are efforts to continue the access and exploits forests DOI: 10.25077/jantro.v20.n1.p1-15.2018

JANTRO ISSN: 2355-5963 (Online) under Lisensi Creative Commons Atribusi-BerbagiSerupa 4.0 Internasional unsustainably. The development of the forestry sector in both villages needs to involve the local community as the main actors of development with the aim of sustainable use of the environment and focus on community welfare (Sunderlin et al., 2000).

Planning, determining development goals and poor criteria, and also technical implementation of poverty alleviation by government or authorized agencies are often centralized (top-down policies). The programs implemented still highlight sectoral ego, thus making the programs not syner gistic and focused. This situation will more difficult as many departments or agencies have different poverty criteria in each region.

Many poverty reduction programs fail as unsuitable specific needs of communities. This problem will impact on the loss of opportunities to improve their potential and environment resources to get out of poverty (Prawoto, 2009).

It is important to understand the reasons for the poverty and the policies in helping the two villages out of poverty. This study aims to analyze the factors that affecting poverty, the relevance and sustainability of the Sustainable Liveli hood Approach in poverty.

\section{B. METHODS}

$T$ his research was conducted in the Village of Argosari, Jabung Subdistrict and the Village of Mentaraman, Donomulyo District, Malang Regency in 90 days. Argosari is a mountainous area with an average height of 800 ASL (Above Sea Level). This village has less developed economic activity and most of villagers work as forest farmers. The population mobility at village is high. The quality of human resources is relatively minimal. Mentaraman has similarities in most of Argosari's social conditions, but has smaller economic activity. Its geographical contours are dry stone beach areas of $50 \mathrm{ASL}$.

In this research, sustainable live lihood approach (SLA) method which adapted on five elements: human, natural, physical, social and financial asset are applied. The SLA method will gives a poverty reduction strategy, when imple 
mented in the forest area, is expected to be able to make the welfare of the population increase.

In this study, poverty as variables influenced by other variables ( 9 variables, see table 1) are described in nine indicators: the frequency of buying meat $/ \mathrm{milk} /$ chicken, the frequency of family meals in a day, the number of new clothing purchases in a year, household income in a month, the number of dependents of the family, the ability to seek treatment at Community Health Center (Puskesmas), the presence of sanitation, the highest education, and the ability to send their 7-15 years children to school. We also provide indicators variables that affect poverty (table 1).

Table 1. Poverty and Assets Indicators

\begin{tabular}{|c|c|}
\hline Variable & Indicators \\
\hline \multirow[t]{9}{*}{ Poverty } & The number of times meat / fish a week (Y1) \\
\hline & Number of meals in a day (Y2) \\
\hline & Number of sets of new clothes in a year usually purchased (Y3) \\
\hline & Total household income (Y4) \\
\hline & Number of dependents of the family (Y5) \\
\hline & Ability to go to hospital (Y6) \\
\hline & There is / no sanitation in poor households (Y7) \\
\hline & Education last head of household (Y8) \\
\hline & Ability to educate children aged $7-15$ years $(Y 9)$ \\
\hline \multirow[t]{7}{*}{ Human Asset } & Existence of school in research area (elementary and junior high school) \\
\hline & (25) \\
\hline & Distance from house to school (X1.2) \\
\hline & There is / no training (X1.3) \\
\hline & There is / no health center / polyclinic (X1.4) \\
\hline & Distance from house to puskesmas / policlinic (X1.5) \\
\hline & Education last head of household (X1.6) \\
\hline \multirow[t]{5}{*}{ Natural Asset } & Origin of clean water source (X2.1) \\
\hline & Source of drinking water (X2.2) \\
\hline & Source of bath water, washing, latrine (X2.3) \\
\hline & $\begin{array}{l}\text { Never / never natural disasters (floods, landslides, tsunamis, etc.) occurred } \\
\text { in the last year (X2.4) }\end{array}$ \\
\hline & There is / no forest / sea in the research area (X2.5) \\
\hline \multirow[t]{10}{*}{ Financial Asset } & Where to do permanent work (X3.1) \\
\hline & Number of household income (X3.2) \\
\hline & Total savings (X3.3) \\
\hline & Loan amount (X3.4) \\
\hline & Amount of (credit) (X3.5) \\
\hline & Number of jewelry (gold) (X3.6) \\
\hline & Home ownership (X3.7) \\
\hline & The wide of the building occupied (X3.8) \\
\hline & The amount of other valuables stuffs (X3.9) \\
\hline & Distance to market (X3.10 \\
\hline \multirow[t]{4}{*}{ Physical Asset } & Availability of public transport (X4.1) \\
\hline & Availability of village markets (X4.2) \\
\hline & Village road type (X4.3) \\
\hline & Availability of information faciliies (X4.4) \\
\hline \multirow[t]{5}{*}{ Social Asset } & Network (X5.1) \\
\hline & Influence of group activities with household income (X5.2) \\
\hline & $\begin{array}{l}\text { There is / is not and how many times the asset assistance for the } \\
\text { population in the study area (X5.3) }\end{array}$ \\
\hline & $\begin{array}{l}\text { There are / no regulations / norms (conventions) that bind the community } \\
\text { to the study area (X5.4) }\end{array}$ \\
\hline & There is / no religious activity, culture, village tradition is followed (X5.5) \\
\hline
\end{tabular}




\section{Human Asset}

Human are equipped by skill, knowledge, ability to work and good health that enable to pursuing various strategies in their work and achievement of life. Human asset varies according to household size, skill level, and health status. Therefore, a change in this asset not only has a great effect, but becomes a supporting factor for other assets.

\section{Nature Asset}

The housholds in forest edge are closely related to the surrounding natural resource assets, such as land, water, forest, and livestock. This asset plays an important role for the production of food and cash. The methods of accessing this asset need to be known to understand the conditions of community processes in improving them selves over time. The vulnerability that occurs to this asset, such as the emergence of natural disasters, also affects the type of work and social conditions.

\section{Financial Asset}

The financial asset in village area comes from a conversion process of production to cash. This indicates that most of vllagers do not have no investment or reservers to meet the insindental needs. This asset includes formal or informal credits as reserves of financial capital. The existence of financial asset shows great supports for their job and life. The two main sources of financial asset consist of cash, deposit, or reserves in the form of livestock, jewelery and regular income consisting of salaries, pensions, or transfers.

\section{Physical Asset}

Physical asset can be in the form of equipments or non-moving infrastructure. Access to this asset will affect the human ability to achieve improved living standards. Physical asset is required in the work of families, such as the presence of transportation, irrigation, energy, and infor mation media. This is very important in a job sustainability. Lack of physical asset in society will hinder education, health care, and income access.

\section{Social Asset}

This asset is related to the way people connect and work together, whether in a household or in a wider community. Wellconnected households will jointly rely on social obligations and mutual support. All parties can play a role in times of crisis. Knowledge of social asset will reveal the ability to acquire and perform work.

The sample was determined by proportional random sampling method (125 respondents in each study site). The study population is the whole object of research or community living in the edge area of the forest. For quantitative data, Propotional Random Sampling was selected, because the study population has non-homogeneous data elements and stratified proportionally. For qualitative data obtained from the selected key people by purposive sampling (number of key informant=3). While deci sion is determined by snow ball sampling approach. Methods of Participatory Rapid Appraisal (PRA) were used in this study, including: interviews, documentation, obser vation, questionnaires, secondary data collection. This research used question naires as instrument and Likert scale (see table 2) in the form of stated category, ranks, and distance of measured construction. This study questionnaire uses five alternative answers that will be chosen by the respondents. The answer given has values corresponding to the items compiled with answers that have a range of positive to negative.

Secondary data is obtained to support the interpretation of result. This data is collected from the agencies or institutions that associated in this research. All data collected in processed and ready-to-use forms. Sample data obtained from the Regional Planning Board (BAPPEDA) Malang Regency, Central Bureau of Statis tics (BPS), Village and District Government. 
Table 2. Likert Scale Rating

\begin{tabular}{ccc}
\hline Answer choices & Skor & Keys \\
\hline A & 5 & Strongly agree \\
B & 4 & Agree \\
C & 3 & Neutral \\
D & 2 & Disagree \\
E & 1 & Strongly disagree \\
\hline
\end{tabular}

\section{Statistical Analysis}

Validity test

Pearson product moment correlation tech nique is used as a validity test method. The correlation used is the correlation between the item score and the total. Furthermore, items that have a positive correlation with a high total score have a high degree of satisfaction (Sugiyono, 2007). The corre lation between each score with total score has minimum requirement when $r \geq 0,3$. If the correlation $r<0.3$, then the instrument item does not meet the validity.

\section{Reliability test}

The tests are performed by measuring the reliability of repeated instruments and will result in the consistent or slightly varying data. The alpha method from Cronbach test model is used as test model (Supranto, 1997).

\section{Descriptive Statistics Analysis}

Descriptive analysis is used to determine the description of the respondents measured from a number of indicators in question. The assumption of multivariate normality was tested by the assistance of AMOS 6 software with an indication of the critical ratio value compared to the critical value $\mathrm{Z}^{2}$ for $\alpha$ $5 \%$.
Inferential Statistics Analysis: Structural Equation Modeling (SEM)

The quantitative approach in this study using descriptive analysis of quantitative and Structural Equation Mo deling (SEM) (Ferdinand, 2002). The Structural Equation Model (SEM) used some classical assump tions as the first step in this research. The assumptions that must be filled in the procedure and data processing to be analyzed in SEM modeling are normality, linearity and outlier (Ferdinand, 2002). Testing the assumption of SEM is used to find out how accurate SEM analysis has been done, including also assess the results of the SEM analysis. The result of this SEM assumption assay using normality test and outlier test. Where the normality test is used to see the normality of the processed data, while the test outliers to see whether there is data damaged in this study. The commonly used of SEM calculation is Analysis of Moment Structures (AMOS) ver. 6. SEM is a method used to test a developed theory whose proof requires empirical testing. SEM is not to establish causality theory, but to test it in a structural equation. The constructed theoretic model describes the causality relationship to be tested through the flowchart. The arrows show a direct causal relationship between the components of the construction (Figure 1). 


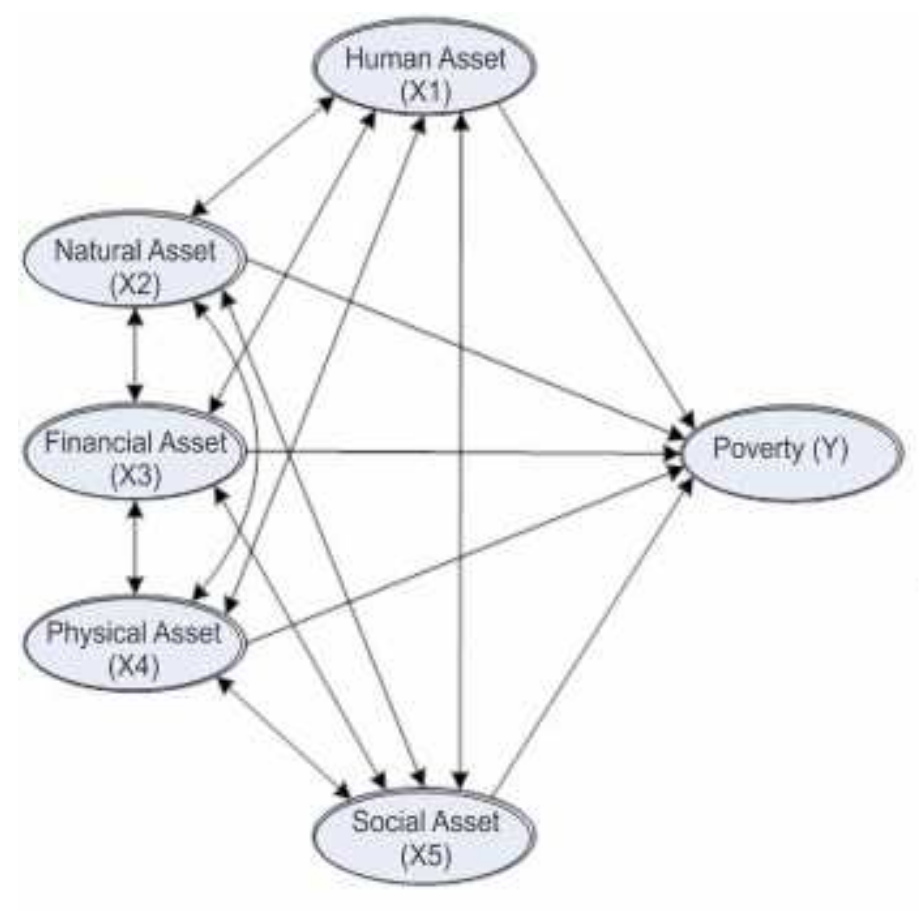

Figure 1. Causal relationships between components of construction

The construction that built on the flow chart can be divided into two groups of variables: exogenus, that consisting of human asset (X1), nature (X2), finance (X3), physical (X4), and social (X5) and endogenous, that consisting of poverty $(\mathrm{Y})$. Exogenous variables are also known as source variables or independent variables, which are unpredictable variables by other variables. Endogenous variables are known as dependent variables that are factors that can be predicted by one or more other exogenous or endogenous variables.

\section{Qualitative Analysis}

Interview results are analyzed descrip tively in-depth, so it can supports the meaning in quantitative research's results (Sugiyono, 2008). Comparation was done to uncover poverty problems that occurred at the study sites. Qualitative research data is a definitive, evidence, and compiled by observation and interview method. The criteria of data in qualitative research is definitive data through observation and interview. If the data is still doubtful, then the research continues until the point of saturation of information. Data collection is guided by facts found on the field. Therefore, qualitative data analysis is an inductive based on the facts.

Qualitative methods are used to obtain deep and meaningful data. The data has a value behind the explicit. Therefore, DOI: 10.25077/jantro.v20.n1.p1-15.2018

JANTRO ISSN: 2355-5963 (Online)

under Lisensi Creative Commons Atribusi-BerbagiSerupa 4.0 Internasional

6 | P a g e qualitative research does not emphasize generalization, but rather emphasizes the meaning of data or findings (Sugiyono, 2008).

\section{RESULTS AND DISCUSSION}

Normality test

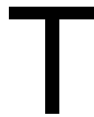
he multivariate normality assumption shows 2.32. The value of the normal ratio for normal multivariate is 2.082 for Argosari Village, and 1.444 for Desa Mentaraman. Because all critical ratio values are below 2.32, so the assumption of normality is fulfilled.

\section{Test Results SEM Assumptions}

Five of the six indicators that tested in Argosari significantly influence poverty (table 3). This is provede by p-value of all 
indicators is smaller than $5 \%(0.05)$. Based on the size of the standardize coefficient, it is found that the Poverti Gap 2 indicator (the number of dependents of the family) has the greatest contribution to the formation of poverty in Argosari Village. The High Consumption 3 indicator (the number of new clothing in a year that can be bought) is an indicator that has the smallest contribution to forming poverty in Argosari Village.

Households that have a larger number of family members are relatively poorer than those who do not. The level of poverty is influenced by the perception of the poor itself, or the level of family consumption (Sarman, 1997). In the case of Argosari Village, poverty is more influenced by the wrong perception of the community towards household management. The desire to have multiple offspring is not matched by income and investment, resulting on the increase of expenditure.

Table 3. Result of Measurement Test of Poverty Variable (Y) Argosari Village

\begin{tabular}{lcc}
\hline \multicolumn{1}{c}{ Indicator } & $\begin{array}{c}\text { Standardized } \\
\text { Coeficient }\end{array}$ & p-value \\
\hline High Consumption 1 (Y1.1) & 0.542 & 0.001 \\
High Consumption 2 (Y1.2) & 0.515 & 0.001 \\
High Consumption 3 (Y1.3) & 0.379 & 0.008 \\
Poverti Gap 2 (Y1.5) & 0.662 & 0.001 \\
Education 1 (Y1.8) & 0.431 & 0.004 \\
Education 2 (Y1.9) & 0.574 & 0.001 \\
\hline
\end{tabular}

Interview results reveal that income and employment to be the basic problem of poverty in Argosari. There is limited employment reduces the opportunity for people to earn income, whereas the number of people entering the productive age continues to increase. Most of the people of Argosari Village only work as farmers, breeders, or farm laborers, and the income is not received intensively, either weekly or monthly. One of Argosari's public figures also confirmed that the main indicator affecting poverty in Argosari Village is the lack of income caused by limited employment. If these facts are attributed to the SEM test results, then each dominant indicator of the SEM test results with the dominant indicator of community perception results has a close relationship. These indicators have very complicated cross-links. With the lack of income, more family members will face difficulties on fulfilling the necessities of life which causing them become poor (Ibrahim and Umar, 2008; Apata et al., 2010; Muhammedhussen, 2015).

Significantly, eight indicators have established the Poverty variable in Mentaraman Village (table 4), which is indicated by a $p$-value less than $5 \%(0.05)$. Based on the size of the standardize coefficient, it is found that the Poverti Gap 2 indicator (the number of dependents of the family) has the greatest contribution to the formation of poverty in Mentaraman Village. On the other hand, the indicator High Consumption 3 (number of new clothing in a year that can be purchased) is the indicator that has the smallest contribution to form poverty in Mentaraman Village. The influence of poverty indicators in Mentraman village is very similar to that of Argosari Village, where the family members provide a very big role to poverty. 
Table 4. The Result of Poverty Variable (Y) test on Mentaraman Village

\begin{tabular}{lcc}
\hline \multicolumn{1}{c}{ Indicator } & Standardized Coeficient & P-value \\
\hline High Consumption 1 (Y1.1) & 0.493 & 0.001 \\
High Consumption 2 (Y1.2) & 0.349 & 0.001 \\
High Consumption 3 (Y1.3) & 0.436 & 0.001 \\
Poverty Gap 1 (Y1.4) & 0.264 & 0.003 \\
Poverty Gap 2 (Y1.5) & 0.572 & 0.001 \\
Health (Y1.7) & 0.277 & 0.002 \\
Education 1 (Y1.8) & 0.465 & 0.001 \\
Education 2 (Y1.9) & 0.495 & 0.001 \\
\hline
\end{tabular}

The results of the interviews reveal an interesting thing, where culture Mbecek or Buwuh also being a barrier to economic progress in Mentaraman. Mbecek is a culture which people have to give some money in an envelope to the people who hold a large activity as a respect forms or financial aid. Culture Mbecek finally impacted on the cash flow of the community. Very little income burden somes society to keep following this culture. The form of participation on mbecek resulted in a financial diversion from the primary needs of the family towards the tertiary sector. On the other hand, people who do not participate in these cultural activities will get heavy social sanctions: ignorance or cessation of assistance from the community.

The test results of variable variables between models in two villages is shown by table 5. The influence of Human Asset on Poverty,was obtained by SEM model structural coefficient of -0.361 with $P$-value value of 0.037 . P-value value $<0.05$ illustrates that the statement "there is the influence of Human Asset on Poverty" is acceptable. The coefficient of structurally modeled negative sign (-0.361) indicates the influence of both negative and vice versa. This means showing the higher Human Asset, will leads to lower levels of poverty, and vice versa.

Table 5. The Linkage Result of Influence of Independent to Dependent Variables

\begin{tabular}{ccccc}
\hline \multicolumn{1}{c}{ Village } & $\begin{array}{c}\text { Independent } \\
\text { Variables }\end{array}$ & SEM Coefisient & p-value & Description \\
\hline Argosari & Human Asset & -0.361 & 0.037 & Significant \\
& Nature Asset & - & - & - \\
& Financial Asset & -0.602 & 0.003 & Significant \\
& Physical Asset & -0.171 & 0.152 & Nonsignificant \\
Mentaraman & Social Asset & -0.323 & 0.010 & Significant \\
& Human Asset & -0.475 & 0.003 & Significant \\
& Nature Asset & - & - & - \\
& Financial Asset & -0.834 & 0.001 & Significant \\
& Physical Asset & - & - & - \\
& Social Asset & -0.057 & 0.297 & Nonsignificant \\
\hline
\end{tabular}

Description: the (-) sign states that the variable is not included in the model

Effect of Financial Asset on Poverty, obtained SEM model of structural coefficient of -0.602 with P-value of 0.003 . P-value $<0.05$ illustrates an association that states "there is influence of Financial Asset on Poverty" is acceptable. The coefficient of structurally modeled negative $(-0.602)$ indicates the influence of both negative and vice versa. This means that the higher the Finance Asset, will lead to lower levels of poverty. Otherwise, the lower of Financial Asset, will result in a higher level of poverty

DOI: 10.25077/jantro.v20.n1.p1-15.2018

JANTRO ISSN: 2355-5963 (Online)

under Lisensi Creative Commons Atribusi-BerbagiSerupa 4.0 Internasional

$8 \mid \mathrm{P}$ a g e 
in Argosari Village. The influence of Physical Asset to Poverty, was obtained by SEM model of structural coefficient of -0.171 with $\mathrm{P}$-value value of 0.152 . Value of P-values 0.05 , indicated the relationship that states "there is influence of Physical Asset on Poverty" is not acceptable. This indicates that Physical Asset will not affects the Poverty Level. The effect of Social Asset on Poverty was obtained by SEM model coefficient of structural -0.323 with P-value 0.010 . P-value $<0.05$ can describe the existence of a relationship that states "there is influence of Social Asset on Poverty" is acceptable. The coefficient of negative structured model $(-0.323)$ indicates that both are negative or opposite. This means that the higher the social Asset, will leads to lower levels of poverty and vice versa (Uphoff and Wijayaratna, 2000; Grootaert, et al., 2002; Rigg, 2006; Santini and De Pascale, 2012; Javed-bin-Kamal, 2014; Tenzin et al., 2015; Tenzin and Natsuda, 2016).

Based on the results of the analysis, the level of poverty in Argosari Village is significantly influenced by Human Asset, Financial Asset, and Social Asset. The most powerful variable of influence is determined by the magnitude of the structural coefficients. Finance is the most powerful asset affecting poverty levels in Argosari Village. In the other side, Poverty in Mentaraman Village involves three independent variable : Human Asset, Financial Asset, and Social Asset. As obtained by SEM coefficient of structural model, the influence of Human Asset to Poverty is equal to -0.475 with value of $P$ value equal to 0.003 . P-value $<0.05$, then the relation states as "there is influence of Human Asset on Poverty" is acceptable. The coefficient of structural model with negative sign $(-0.475)$ indicates the influence of both negative or opposite, which means the higher Human Asset will result in lower levels of poverty and vice versa.
The influence of Financial Asset to Poverty was obtained by SEM coefficient of structural model -0.834 with P-value 0.001 . Because of the value of $P$-value is $<0.05$ then the relationship that states "there is influence of Asset Finance to Poverty" is acceptable. The coefficient of structurally modeled by negative sign $(-0.834)$ which indicates the influence of both negative or vice versa. This means that the higher Finance Asset will leads to lower levels of poverty. Otherwise, the lower Finance Asset, will result in the higher level of poverty in Mentaraman Village.

Influence of Social Asset to Poverty was obtained by SEM model coefficient of structural -0.057 with P-value 0.297 . Because of the P-value is $>0.05$ then the relationship that states "there is influence of Social Asset on Poverty" is unacceptable, meaning that amount of Social Asset will not affect the Poverty Level. The SEM results indicate that the poverty rate in Mentaraman Village is only significantly affected by Human Asset and Financial Asset. The most powerful variable of influence is determined by the amount of the structural coefficients. Finance Asset is the most powerful asset affected to the poverty levels. The result of correlation test between asset in sustainable livelihood approach (SLA) in Argosari Village shows the relationship between human asset with physical asset, and financial asset with social asset (table 6). On the other side, there is no relationship between human asset and financial asset, human asset with social asset, financial asset with physical asset, as well as physical asset with social asset. This evidence can be as policy advices on poverty alleviation in Argosari Village, where the most important requirement is the linkage between human asset with physical asset and financial asset with social asset. More attention to asset-toasset relations is basic for which policies can be applied appropriately and efficient (Dorward et al., 2002). 
Table 6. Results of Linkage Testing Influence between Independent Variables

\begin{tabular}{ccccccc}
\hline Village & \multicolumn{2}{c}{$\begin{array}{l}\text { Linkage between the } \\
\text { Independent Variables }\end{array}$} & $\begin{array}{c}\text { SEM } \\
\text { Coeficient }\end{array}$ & p-value & Description \\
\hline Argosari & Human & - & Nature & - & - & - \\
& Human & - & Financial & 0.280 & 0.109 & NonSignificant \\
& Human & - & Physical & 0.467 & 0.002 & Significant \\
& Human & - & Social & 0.118 & 0.402 & NonSignificant \\
& Nature & - & Financial & - & - & - \\
& Nature & - & Physical & - & - & - \\
& Nature & - & Social & - & - & - \\
& Financial & - & Physical & 0.148 & 0.317 & NonSignificant \\
& Financial & - & Social & 0.404 & 0.013 & Significant \\
& Physical & - & Social & 0.043 & 0.723 & NonSignificant \\
& Human & - & Nature & - & - & - \\
& Human & - & Financial & 0.771 & 0.001 & Significant \\
& Human & - & Physical & - & - & - \\
& Human & - & Social & 0.042 & 0.737 & NonSignificant \\
& Nature & - & Financial & - & - & - \\
& Nature & - & Physical & - & - & - \\
& Nature & - & Social & - & - & - \\
& Financial & - & Physical & - & - & - \\
& Financial & - & Social & 0.040 & 0.754 & NonSignificant \\
& Physical & - & Social & - & - & - \\
\hline
\end{tabular}

Interviews in Argosari village show that financial asset, human asset, social asset and natural asset are the main causes of poverty (see figure 2). The influence of financial asset comes from the lack of income. In-depth observation shows the lack of employment to be a major factor in financial asset problems. In addition, there is a constriction of existing employment. This resulted in the ownership of agricultural land in Argosari Village began to shift ownership to outsiders of Argosari Village or being leased. This creates a financial flow that benefits the community from outside the village. Outsiders work on their farms by their own labors. This ultimately induced an increasing number of Argosari unemploy ment or contract workers.

The limited conditions of employment are also influenced by the human resources of Argosari Village. The people argue that their poverty is due to their limited knowledge, especially about managing finances and knowledge of farming techniques. Poor financial management leads to a lack of savings when their income is excessive. Instead, they use it for more consumptive purposes, and not on the productive sector or investment. This makes their incomes will run out in a short time.

Interview results also illustrate that social asset also plays a role in in Argosari poverty (see figure 3 ). Early marriage culture and dependent personals are very often seen in the community. The first fact, early marriage, is always not accompanied by mental awareness, future planning, and a good economy condition. The condition of couples coming from impoverished families, marriage is likely to aggravate family conditions and put more new families on the list of poor communities. 


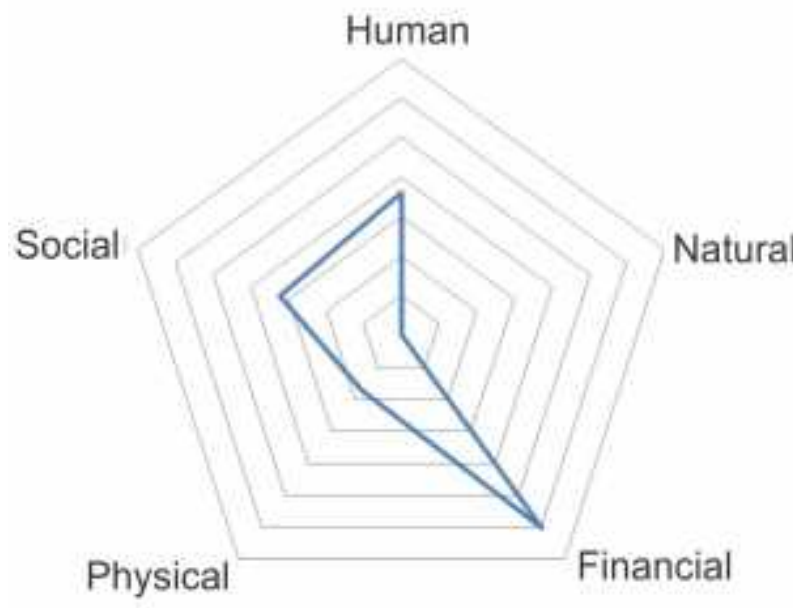

Figure 2. Interconnection Chart Influence Between SLA Factors in Argosari Village

On the other hand, the behavior of receiving aid from other makes people very difficult to develop and empower the village potential. Special aid to the poor have become untargeted, with many capable villagers finally got the donations. The village development assistance can not be utilized optimally, and only switch to consumptive sectors. Most of people still waiting more for help without making efforts to improve their lives.

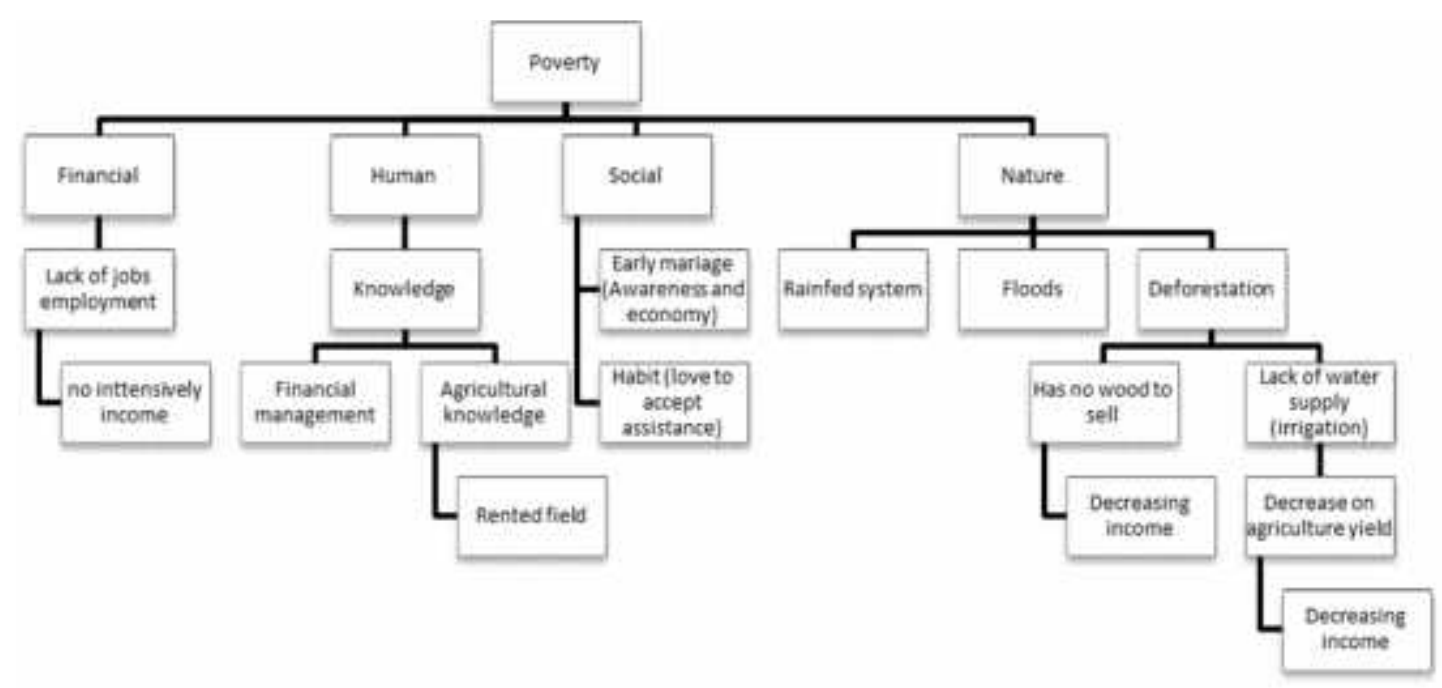

Figure 3. Root Diagram of Argosari Village Problem

Natural asset is also considered to have an influence on poverty in Argosari Village. The climatic conditions of the village area was very dry. This fact makes the most of the existing paddy fields with a rain-fed system can only be planted once a year. In addition, deforested process in the surrounding mountains can cause landslides and floods that destroy public and private facilities, such as houses, roads, irrigation facilities, rice fields, and secondary forest areas. Since 2008, communities through independent awareness have conserved mountain slopes by planting trees on a small

DOI: 10.25077/jantro.v20.n1.p1-15.2018

JANTRO ISSN: 2355-5963 (Online)

under Lisensi Creative Commons Atribusi-BerbagiSerupa 4.0 Internasional 
scale (Leakey et al., 2005, 2007; Asaah et al., 2011).

The linkage between asset in a sustainable livelihood approach in Mentaraman Village shows that the three asset are not linked each other (see figure 4). There are only three assets affecting the level of poverty in Mentaraman village and they dont have relevance. This evidence indicates that policy of poverty alleviation in this region does not to pay attention to the relevance among the three assets. These three assets can be the subject of policy goals without having to worry about the interrelationship between them.



Figure 4. Linkage Diagram of Influence among the SLA Factors in Mentaraman Village

The observation to some poor households in Mentaraman Village shows that the main factor causing poverty is the income. Average community income is not more than IDR 500,000 per month. This makes the community only able to fulfill the primary needs. Based on the SLA linkage analysis, it can be assessed that one of the poverty solutions through direct cash assistance will have a very small impact (Marini, 2015). In contrast, low income should receive more attention in the development of poverty reduction strategies.

The results of the disclosure through deeper interviews show the very low number of people who have permanent jobs in Mentaraman village. This has an impact on the low income per month. Most of people work as manual laborers with contract work systems. The low educational factor is thought to be the main cause of the contracting system that is widely embraced by the community. The low level of education makes people experience a very difficult competition situation $(\mathrm{Ng}$ and
Feldman, 2009; Kotur and Anbazhagan, 2014).

In contrast, low education is due to the inability of society to finance the education (see figure 5). Some educational compositions, such as monthly payment, books, and transportation are considered too expensive and unreachable. In addition, public perception and awareness of education is still quite negative. Interview results reveal that education will not directly alter the fate of a poor family.

Nature becomes a supporting factor of the growth of poverty in Mentaraman village. The topography of the village consisting of limestone mountains and rocks has caused a lack of land that can be done by the community as an agricultural area. In addition, the topography causes a lack of water supply for villages and agricultural areas. Reforestation of forest areas on mountain slopes provides improvements to the water supply, although it dominated for the primary needs of the community, not agriculture. Only 15 of the 3400 hectares of village areas are agricultural land in the form 
of rain-fed systems. Therefore, the community uses more polyculture agroforestry system using the forest trees on the slopes of the mountains (Leakey et al., 2005; Leakey et al., 2007; Tchoundjeu et al., 2010; Asaah et al., 2011).

Mentaraman village has major agricultural commodities: belinjo, banana, and coconut. However, direct and simple sales are still implemented by the community. There is still no significant increase activity on the value of the commodity. Among the three commodities, belinjo became the most processed commodity so it can distribute to other markets outside the village.

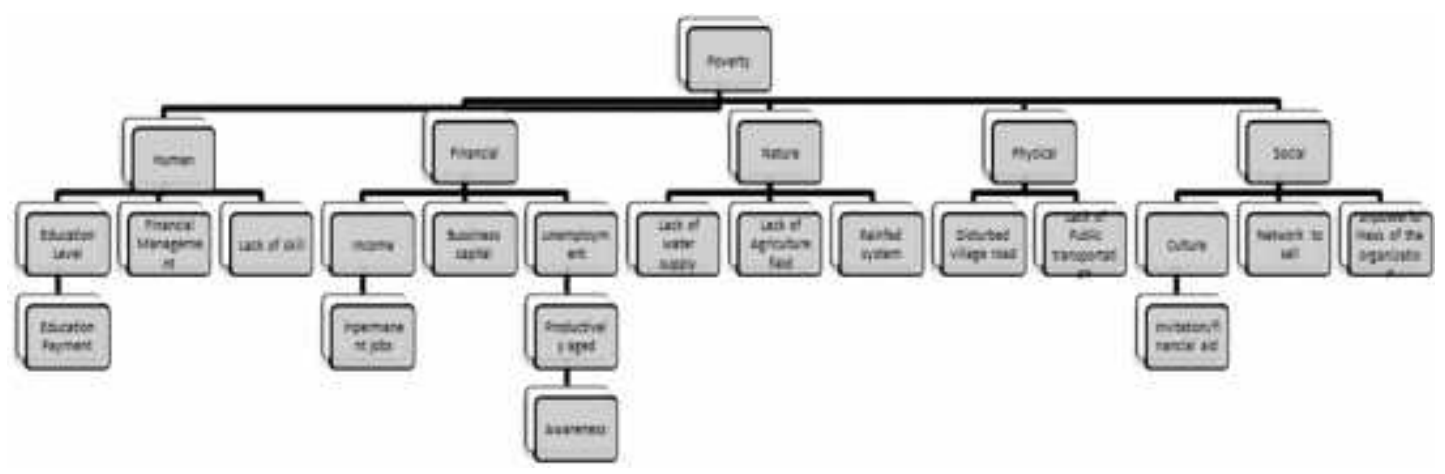

Figure 5. Root Diagram of Mentaraman Village Problem

\section{CONCLUSION}

ncome is the main indicator of the financial asset of the poverty factor in Argosari and Mentaraman. Low income due to inability to get a permanent job. Inability to get a job due to lack of skills / knowledge and financial management ability is very limited. Marriage at an early age is also one of the contributing factors. Habit of communities that like to accept assistances also affects the difficulty of the community getting out of poverty. Nature is also a cause of poverty where climate and barren mountain slopes often damages public and private facilities in Argosari village and result in a lack of water supply for people and farmland in Mentaraman.

\section{E. ACKNOWLEDGMENT}

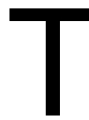
he authors are grateful to BAPPEDA Malang, BPS, and Malang Regency Government for secondary data and research permit. We also thank the respondents and the study villagers for the information, field assistance and data required.

\section{References}

Ananta, A., Bauer, A., \& Thant, M. (2013). The Environtments of the Poor in Southeast Asia, East Asia, and the Pacific. Pasir Panjang : ISEAS Publishing.

Angelsen, A. \& Wunder, S. (2003) . Exploring the Forest-Poverty Link. CIFOR Occasional Paper, 40, 1-20.

Apata, T. G., Apata, O. M., Igbalajobi, O. A. \& Awoniyi, S. M. O. (2010). Determinants of rural poverty in Nigeria: Evidence from small holder farmers in South-western, Nigeria. Academic Journals. Journal of Science and Technology Education Research, 1, $85-91$. 
Asaah, E.K., Tchoundjeu, Z. Leakey, R.R.B., Takousting, B., Njong, J. \& Edang, I. (2011). Trees, agroforestry and multifunctional agriculture in Cameroon. International journal of agricultural sustainability, 9, 110-119.

BPS. (1999). Perkembangan Tingkat Kemiskinan dan Beberapa Dimensi Sosial Ekonominya 1996-1999. Jakarta: BPS

Dewi, S., Belcher, B. \& Puntodewo, A. (2005). Village Economic Opportunity, Forest Dependence, and Rural Livelihoods in East Kalimantan, Indonesia. World Development, 33, 1419-1434.

DPMD. (2017). Desa-desa Kategori Miskin di Jawa Timur. Accessed on November 16, 2017. http://www.dpmd.jatimprov.go.id.

Ferdinand, A. (2002). Structural Equation Modeling dNature Penelitian Manajemen. Semarang : Badan Penerbit Universitas Diponegoro.

Fikir, D., Tadesse, W, \& Gure, A. (2016). Economic Contribution to Local Livelihoods and Households Dependency on Dry Land Forest Products in Hammer District, Southeastern Ethiopia. International Journal of Forestry Research, 2016, 1-10.

Fisher, M. (2004). Household Welfare and Forest Dependence in Southern Malawi. Environment and Development Economics, 9, 135-154

Grootaert ,C., Oh, G.-T. \& Swamy, A. (2002). Social Capital, Household Welfare and Poverty in Burkina Faso . Journal of African Economies, 11, 4-38.

Hamzah, A. (2012). Policy Tackling the Poorness and Hunger in Indonesia : Reality and Study. Jurnal AKK. 1, 1, 48-55

Husken, F. (1998). Masyarakat Desa di Nature Perubahan Zaman : Sejarah Diferensiasi Social di Jawa 1830-1980. Jakarta: PT Grasindo.

Ibrahim, H. \& Umar, H.S. (2008). Determinants of Poverty among farming Households in Nasarawa State, Nigeria. Media and Agricultural Marketing, 4, 11-21.

Javed-bin-Kamal. (2014). Asset Based Poverty and Wealth Accumulation in Low Income Households in Bangladesh. Bangladesh Development Studies, 37, 35-51.

Kartodiharjo, H. \& Hira J. (2005). Politik Lingkungan dan Kekuasaan di Indonesia. JakartaSingapore : Equinox Publishing.

Kotur, B. \& Anbazhagan, S. (2014). Education and work-experience - Influence on the performance. IOSR Journal of Bussiness and management, 16, 104-110

Krantz, L. (2001). The Sustainable Livelihood Approach to Poverty Reduction : An Introduction. Swedish: Swedish International Development Cooperation Agency.

Leakey, R. R. B., Tchoundjeu, Z., Schreckenberg, K., Shackleton, S., \& Shackleton, C. (2005). Agroforestry tree products (AFTPs): targeting poverty reduction and enhanced livelihoods. International Journal of Agricultural Sustainability, 3, 1-23.

Leakey, R. R. B., Tchoundjeu, Z., Schreckenberg, K., Simons, A. J., Shackleton, S., Mander, M., Wynberg, R., Shackleton, C., Sullivan, C. (2007). Trees and markets for agroforestry tree products: targeting poverty reduction and enhanced livelihoods. In: D. Garrity, A. Okono, S. Parrott (eds), World Agroforestry into the Future, World Agroforestry Centre, Nairobi, Kenya, p.11-22.

Li, T. M.. (2002). Proses Transformasi Daerah PedNaturean di Indonesia. Jakarta: Yayasan Obor Indonesia.

Lyman, M.W., Grimm, C., \& Evans, J.R. (2014). Community Forests as a Wealth Creation Strategy for Rural Communities. Journal of Community Development, 45, 5

Mamo, G., Sjaastad, E. \& Vedeld, P. (2007). Economic Dependence on Forest Resources: A Case from Dendi District, Ethiopia. Forest Policy and Economics, 9, 916-927.

Marini, D. (2015). Dampak penyaluran Bantuan Langsung Tunai (BLT) terhadap Masyarakat Miskin di Desa Perawang Barat, Kecamatan Tualang, Kabupaten Siak. Jom FISIP, 2: 1-10.

Morse, S \& McNamara, N. (2013). Sustainable Livelihood Approach : A Critique of Theory and Practice. Springer. Accessed on November 17, 2017. http://www.springer.com/978-94-007-6267-1 
Muhammedhussen, M. (2015). Determinants of Rural Income Poverty in Ethiopia: Case Study of Villages in Dodola District. Global Journal of Management and Business Research: B Economics and Commerce, 15: 25-32.

Munanura, I.E., Backman, K.F., Moore, D.D., Hallo, J.C. \& Powell, R.B. (2014). Household Poverty Dimensions Influencing Forest Dependence at Volcanoes National Park, Rwanda: An Application of the Sustainable Livelihoods Framework. Natural Resources. 5, 1031-1047.

Prawoto, N. (2009). Memahami Kemiskinan dan Strategi Penanggulangannya. Jurnal Ekonomi dan Studi Pembangunan. 9,1, 56-68

Ng, T. W.H. \& Feldman, D.C. (2009). How Broadly Does Education Contribute to job perfomance? Personnel Psychology. 62, 89-134

Plumptre, A., Kayitare, A., Rainer, H., Gray, M., Munanura, I., Barakabuye, N. \& Namara, A. (2004). The Socio-Economic Status of People Living near Protected Areas in the Central Albertine Rift. WCS, IGCP, CARE Uganda, Kampala.

Rigg, J. (2006). Land, Farming, Livelihoods and Poverty: Rethinking the Links in the Rural South. World Development. 34, 180-202.

Santini, I. \& de Pascale, A.. (2012). Social capital and household poverty: the case of European Union. Working Paper No.109, December 2012. Università degli Studi di Roma "La Sapienza" Via del Castro Laurenziano 9, 00161 Roma (RM).

Sarman, M. (1997). Kemiskinan dan pemberdayaan ekonomi rakyat: pelajaran dari program IDT. Prisma 1 edisi Januari 1997, pp 33-41.

Sugiyono. (2008). Metode Penelitian Kuantitatif, Kualitatif, dan R\&D. Bandung : Alfabeta

Sunderlin, W.D., Resosudarmo, I.A.P., Rianto, E., \& Angelsen, A. (2000). The Effect of Indonesia's Economic Crisis on Small Farmers and Natural Forest Cover in the Outer Islands. CIFOR Occasional Paper. 28 (E).

Sunderlin, W.D., Angelsen, A., Belcher, B., Burgers, P., Nasi, R., Santoso, L. \& Wunder, S. (2005). Livelihoods, Forests, and Conservation in Developing Countries: An Overview. World Development, 33, 1383-1402.

Supranto, J. (1997). Metode Riset, Aplikasinya dalam Pemasaran. Jakarta : PT Rineka Cipta

Tchoundjeu, Z., Degrande, A., Leakey, R. R. B., Nimino, G., Kemajou, E., Asaah, E., Facheux, C., Mbile, P., Mbosso, C., Sado, T., Tsobeng, A. (2010). Impacts of participatory tree domestication on farmer livelihoods in west and central Africa. Forests, Trees and Livelihoods, 19, 217-234.

Tenzin, G., Otsuka, K. \& Natsuda, K. (2015). Can Social Capital Reduce Poverty? A Study of Rural Households in Eastern Bhutan. Asian Economic Journal. 29, 243-264.

Tenzin,G. \& Natsuda, K. (2016). Social capital, household income, and community development in Bhutan: a case study of a dairy cooperative. Development in Practice. 26, 467-480.

Uphoff, N. \& C. M. Wijayaratna. (2000). Demonstrated Benefits from Social Capital: The Productivity of Farmer Organizations in Gal Oya, Sri Lanka. World Development. $28,1875-1890$.

Vedeld, P., Jumane, A., Wapalila, G. \& Songorwa, A. (2012). Protected Areas, Poverty and Conflicts: A Livelihood Case Study of Mikumi National Park, Tanzania. Forest Policy and Economics, 21, 20-31.

Yoserizal., and Yesi. (2018). Conflict Of Interest Among Stakeholders In Tesso Nilo National Park (Tnnp) (Konflik Antar Pemangku Kepentingan Di Taman Nasional Tess Nilo (TNTN)). Jurnal Antropologi: Isu-Isu Sosial Budaya, 19 (2), 101-107. doi:https://doi.org/10.25077/jaisb.v19.n2.p101-107.2017 